\title{
CONSUMER TRUST AS A MEDIATING VARIABLE OF THE EFFECT OF CUSTOMER SATISFACTION ON REPURCHASE INTENTION IN " $X$ " ONLINE STORE
}

\author{
Panggabean Fadjar Biru P.*, Setiawan Putu Yudi \\ Faculty of Economics and Business, University of Udayana, Bali, Indonesia \\ *E-mail: fadjarbirupp@gmail.com
}

\begin{abstract}
The obstacle in the online shopping business for business actors is to instill a sense of consumer trust, evidence of consumer trust by providing rating values and reviews on online stores when shopping. Trust can be built which will not only have an impact on satisfaction, but also on the intention to repurchase the product. This research was conducted on consumers who shopped at online store ' $X$ ' with the purpose of analyzing the role of consumer trust in mediating the effect of consumer satisfaction on repurchase intentions at Online Store ' $X$ '. The number of samples taken as many as 150 respondents with purposive sampling method, where the selection of individuals as a sample of all consumers shopping at Online Store $X$ in the last 12 months. The data analysis technique used in this research is descriptive statistics and SEM AMOS.16. The results showed that: 1) consumer satisfaction had a positive and significant effect on repurchase intention (C.R.=3,306); 2 ) consumer satisfaction had a positive and significant effect on consumer trust (C.R. $=6,884$ ); 3 ) consumer trust has a positive and significant effect on repurchase intention (C. $R=8,438$ ); 4 ) the role of consumer trust in mediating consumer satisfaction has a positive and significant effect on repurchase intentions (Sobel test $=3.026$ ).
\end{abstract}

\section{KEY WORDS}

Consumer trust, customer satisfaction, repurchase intention, online shop.

The application of information technology in the online shopping sector in Indonesia is very rapid, causing numbers of malls, shops, retail stores, and other shopping centers slowly declining, not on the basis of declining purchasing power but on the pattern shift in transactions where people began to do it online (Nuraini and Evianah, 2019). Consumers no longer have to come to the store directly to shop, it is only enough through gadgets that they can shop as needed by visiting various websites or through available applications (Zulfa and Hidayati, 2018). Not surprisingly, consumers are increasingly interested in choosing to shop online rather than offline with its convenience without wasting time and effort. The development of online shopping is supported by incessant promotions from online stores in offering products or services as well as an increase in the level of internet penetration and mobile device users, allowing more people to access various online shopping platforms (Nuraini and Evianah, 2019). The results of the BPS data collection (2019), there are 1.53 percent of e-commerce businesses in Indonesia that have started using the internet before 2010, businesses that started using the internet in 2010 to 2016 were 28.06 percent, businesses that started using the internet in 20102017 to 2018 as many as 45.30 percent, while those just starting in 2019 were 25.11 percent. The presence of various payment applications and features as well as online wallets through gadgets, as well as payments through the Cash On Delivery mechanism also makes it easier for people to make online transactions. According to E-Commerce (2019), Cash on Delivery (COD) is the most widely available payment method in e-commerce businesses in Indonesia compared to other payment methods, which is 83.73 percent. The rest is payment via credit card, transfer, or online loan. Based on the E-Commerce Survey (2019), the types of goods sold in ecommerce businesses, food, beverages, and groceries are the most common items, namely 27.85 percent of the total businesses that are sampled for e-commerce. This can be explained from the media used in e-commerce transactions not only through the marketplace and social media but also through whatsapp. Many food and drink providers such as street 
vendors and restaurants accept orders via WhatsApp. The type of goods sold in e-commerce businesses ranks second most with a proportion of 22.11 percent is clothing while the third is others at $14.17 \%$, the next order is cosmetics at $8.25 \%$, travel products at $7.22 \%$, goods households by $6.02 \%$, gadgets by $4.85 \%$, medicines by $3.7 \%$, books/magazines by $1.99 \%$, electronics by $1.69 \%$, financial products by $0.82 \%$, video games /software by $0.51 \%$, movies/music/video by $0.37 \%$, and tickets for entertainment events by $0.45 \%$. Online shopping (online shopping) is a means or shop to offer goods and services via the internet and can view goods in online stores in the form of pictures, photos, or videos (Sari, 2015). Shopping online is cheaper from the customer's point of view (Valvi and Fragkos, 2012). However, online shopping is still considered riskier than offline shopping, so online stores must always maintain the suitability of the products offered as the key to gaining consumer trust and satisfaction, if they want to repurchase (Lu et al., 2013). Along with the development of online shopping in Indonesia, several marketplaces have emerged which are considered to be able to reduce risk compared to online shopping, because the marketplace is a platform and an intermediary between online stores and consumers, covering products, payments, to delivery. Marketplace from the online store side, provides an opportunity to expand the marketing and reach of the products sold and increase trust. Meanwhile, from the consumer side, the marketplace makes purchase transactions safer and easier because of the many payment options provided by the marketplace. Starting from the availability of options to make payments using installments to the most widely used, namely Cash On Delivery. In addition, marketplace consumers are also given space to convey things related to store services, product quality, and delivery after receiving products through ratings and reviews.

The obstacle in the online shopping business for business actors is to instill a sense of consumer trust, because there are still many consumers who do not believe in online-based shopping, only buyers who have trust will dare to make transactions through internet media, one of which is shown by providing rating and review values. on online stores when making online purchase transactions, where ratings and reviews will determine and can influence the trust of other consumers in online purchase transactions at the store. Online store sellers must always provide and improve the quality of service and good goods in order to create the trust of every consumer. One of the online shopping stores in Bali is Toko Online ' $X$ ' which sells products through the marketplace and has received a rating of $4.9 / 5$ on Tokopedia and Shopee. This proves the satisfaction possessed by consumers which will affect the trust of other consumers, but problems were found, namely from sales data during 2020 only a small percentage of consumers returned to shop, as can be seen in Table 1 below:

Table 1 - Sales Report Data and Percentage of Buybacks for Online Store 'X' in May 2020-April 2021)

\begin{tabular}{lll}
\hline Month & Total Transaction & Repurchase $(\%)$ \\
\hline May 2020 & 125 & 5 \\
June 2020 & 102 & 2 \\
July 2020 & 105 & 4 \\
August 2020 & 129 & 3 \\
September 2020 & 113 & 4 \\
October 2020 & 113 & 4 \\
November 2020 & 101 & 0 \\
December 2020 & 146 & 6 \\
January 2021 & 93 & 2 \\
February 2021 & 100 & 4 \\
March 2021 & 96 & 1 \\
April 2021 & 131 & 4 \\
\hline
\end{tabular}

Source: secondary data (reports on sales and the percentage of repurchases for online shop ' $X$ ' in May 2020-April 2021).

Table 1 above, from the sales report data and the percentage of ' $X$ ' Online Shop repurchases in May 2020 - April 2021 shows the most sales and repurchase presentations in December 2020 of 146 transactions there are $6 \%$ which are repurchases while in November 2020 there is no repurchase percentage or $0 \%$ of total sales of 101 transactions. Each month 
shows an increase and decrease in numbers. This shows a lack of customer trust and repurchase intention at online store ' $X$ '. In terms of the online environment, customer satisfaction is one of the important keys, related to the possibility of increasing customer retention, and the long-term growth of online stores (Lin and Lekhawipat, 2014). Customer satisfaction has a positive and significant effect on repurchase intentions (Lin and Lekhawipat, 2014; Pappas et al., 2014). The results of research by Devi and Sulistyawati (2018) found that customer satisfaction has a positive and significant effect on repurchase intention. Consumers will intend to repurchase when they are satisfied after receiving a product or service (Adixio and Saleh, 2013).

The low percentage of consumers who shop again at Online Store $X$ is contrary to previous research. However, according to research from Juniwati (2015) that satisfaction with online shopping does not have a significant effect on consumers in making and online repurchase intentions on clothing products. Research Weisberg et al. (2011) that trust has a positive and significant effect on repurchase interest. Hinomona and Dubihlela (2014) state that customer satisfaction is an antecedent of trust. Trust is a cumulative process that develops during repeated satisfying interactions between customers and sellers.

According to Bank Indonesia data, total e-commerce transactions in Bali recorded an increase of 27.61 percent in the fourth quarter of 2020 compared to the previous period or an annual increase of 69.84 percent. Based on the initial preliminary survey that the researcher did, the researcher found that there was satisfaction felt by customers as indicated by the rating value of 4.9/5 through the marketplace, but it was not followed by an increase in the number of customers and repurchases at the online store ' $X$ '. Very tight competition from other online business actors, where consumers only get information on goods and sellers from pictures, but do not clearly know the seller's credibility, it is impossible for online transactions to occur without the trust of buyers. Dissatisfaction and lack of consumer confidence are reflected in the existence of consumer complaints about the length of time the goods reach the hands of consumers, it does not match the photo in the picture with the quality of the product received and the product price is more expensive because it has to increase the cost of shipping the product, causing consumers not to making another purchase at online store ' $X$ ' will result in losing a lot of consumers and incurring losses. To be able to survive, online store ' $X$ ' must always be able to analyze complaints and correct deficiencies in order to increase satisfaction which is indicated to affect consumer confidence which ultimately has an impact on consumers' repurchase intentions.

The results of previous studies regarding the effect of consumer satisfaction on repurchase intentions in the context of online services have not been studied much, especially the variable consumer trust as a mediator in online stores that already have a reputation and have been operating for a long time, while research on new online stores that have not been operating for a long time is relatively new. been explored further by previous researchers. On the one hand, studies conducted by Solvang (2007); Yang (2009); Mariska and Shihab (2016); Devi and Sulistyawati (2018); Dwipayana and Sulistyawati (2018); Kadir et.al., (2018); Gustom et.al., (2020), which states that consumer satisfaction affects consumer trust. Elvandri (2011) in his research reveals that consumer satisfaction in conducting online transactions is indicated to have an effect on consumer trust which will ultimately affect consumer attitudes in making repeat purchases (intention to use). Online shopping satisfaction will positively and significantly increase if online sellers are honest and provide complete information, so that higher consumer trust will be formed (Azar et al., 2015).

Research by Suandana et.al., (2016); Palma et al., (2016) show that consumer satisfaction affects repurchase intentions; research by Devi and Sulistyawati (2018), Shidarta et.al., (2018) that consumer trust affects repurchase intentions. On the other hand, the results of a different study conducted by Juniwati (2015) found that satisfaction had no significant effect on repurchase intention. Chen and Chou's research (2012) states that trust has no significant effect on repurchase intentions. Previous research on trust mediating the effect of consumer satisfaction on repurchase intention does not yet exist, but previous research was conducted by Weisberg et al. (2011); Giantari et al. (2013); Suandana (2016); 
Astarina et.al., (2017) stated that trust significantly mediates the effect of experience on intention to reuse. Furthermore, the research as a reference for reviewing this research by changing the variables into a separate study entitled "Consumer trust as a mediator of the influence of consumer satisfaction on repurchase intentions at online store ' $X$ '.

The difference between this study and several previous studies lies in the object of research, namely the online store ' $X$ ', the research variables are trust, consumer satisfaction, and repurchase intentions, while the data analysis uses structural inquiry modeling (SEM) as an analytical tool to obtain more accurate measurement results. accurate. Unfulfilled consumer satisfaction will result in reduced consumer confidence in providers of goods or services. This will contribute to the emergence or absence of consumer repurchase intentions. The obstacle that is also happening to online stores today is that only some consumers give ratings and provide reviews related to purchasing products on the marketplace and only a small percentage of consumers give assessments related to purchasing products when shopping outside the marketplace. This makes sellers can only guess at the level of satisfaction from consumers and question whether there is a possibility that consumers will buy back the products offered or not. When online stores are able to build consumer satisfaction, the possibility of consumers to repurchase at the online store will be even greater which can be formed through consumer trust. Trust can be built which will not only have an impact on satisfaction, but also on the intention to repurchase the product.

Based on the description above, showing that perceived consumer satisfaction does not necessarily affect the intention to reuse when viewed in the results of the preliminary survey, it is important to add trust as a mediating variable. Therefore, the researcher wants to do further research by using the variables of Consumer Confidence and Consumer Satisfaction as a predictor of repurchase intention because it is based on empirical evidence from previous research and wants to see to what extent these predictors are able to influence repurchase intention at online store ' $X$ ', so that the conceptual framework of the research and the formulation of the problem in this study can be formulated as follows:

- H1: Online shopping consumer satisfaction has a significant effect on repurchase intentions;

- H2: Online shopping consumer satisfaction has a significant effect on consumer confidence;

- H3: Consumer trust has a significant effect on repurchase intention;

- H4: Consumer trust mediates the effect of online shopping consumer satisfaction on repurchases intentions.

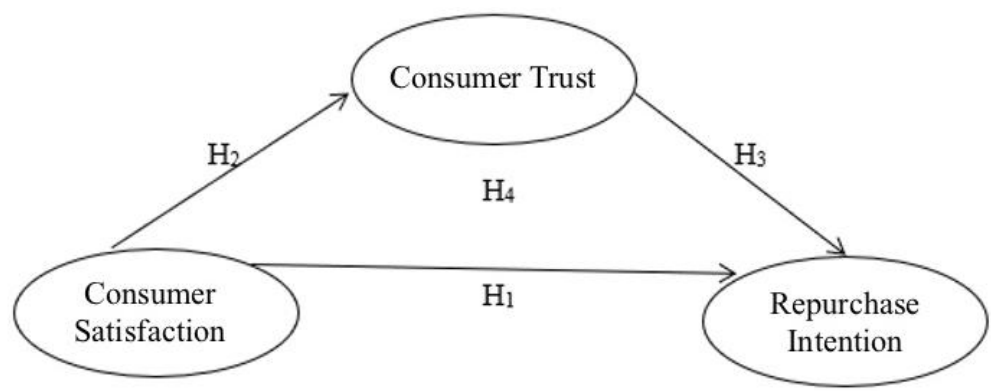

Figure 1 - Research concept framework

\section{METHODS OF RESEARCH}

The design used is the relationship between variables (causal design) which is useful for measuring the relationship between research variables or for analyzing how one variable influences other variables. In this study, the data were collected ex post facto, in other words, the researcher relied on the respondent's perception to explain his experiences and then analyzed according to a causal design. The data collection technique in this study used a research instrument in the form of a questionnaire to respondents who could choose one of 
the answers provided, with alternative answers consisting of an interval of $1-5$. Shoes are located in the South Denpasar area with a total of 150 consumers per month spread throughout Indonesia (secondary data for Online Store X). The scope of this research is to examine repurchase intention, which will be explained by consumer trust as a mediator of the influence of online shopping consumer satisfaction. Therefore, in this study limited to the identified variables only. The data analysis tool used in this research is Structural Equation Modeling (SEM) using AMOS software as an analysis that combines factor analysis approaches, structural models (structural models), and path analysis.

\section{RESULTS AND DISCUSSION}

Based on the results of the questionnaires that have been distributed, it was found that the characteristics of respondents by age with the largest number of respondents were in the age group > 27 - 32 years as many as 50 people (33.3\%). Characteristics of respondents based on gender from 150 people were dominated by male respondents as many as 113 people (75.3\%). Characteristics of respondents based on education are divided into four groups, namely SMA, Diploma, Undergraduate, and Postgraduate. The smallest respondents were in the postgraduate education group, namely 11 people $(7.2 \%)$. While the majority of respondents were in the undergraduate education group as many as 84 people $(56 \%)$. Characteristics based on occupation with the largest number of respondents were in the group with private employees, as many as 80 people (53.3\%). Characteristics based on income with the largest number of respondents in the income group > Rp. 3,000,000 $6,000,000$ that is as many as 48 people $(32.0 \%)$. The model suitability test shows that a model fits or fits the data used in the study. This can be seen from the existing criteria, namely Chi-Square, Probability, CMIN/DF, AGFI, GFI, CFI, TIL, and RMSEA, whether all of them are well received. According to Hair, et al (2010) the suitability test of this model is acceptable or the model is categorized as fit if at least 7 of these criteria are met.

Table 1 - Model Conformity Test Results (Goodness of Fit Test)

\begin{tabular}{lllll}
\hline Fit Indicator & Recommended Value & Model Evaluation & Research result & Information \\
\hline Absolute Fit & & & & \\
Probabilities & $\mathrm{P}>0,05$ & Not Sig & 0,074 & Fit \\
Normed Chi Square $\left(\mathrm{x}^{2} / \mathrm{df}\right)$ & $<2$ & Over Fitting & 1,240 & Fit \\
& $2<\mathrm{x}^{2} / \mathrm{df}<5$ & Good Fit & & Git \\
RMSEA & $<0,08$ & Good Fit & 0,040 & Fit \\
GFI & $>0,90$ & Good Fit & 0,923 & Fit \\
AGFI & $>0,90$ & Good Fit & 0,911 & Fit \\
Comparative Fit & & Good Fit & 0,944 & Fit \\
NFI & 0,90 & Good Fit & 0,984 & Fit \\
Index (TLI) & 0,90 & Good Fit & 0,988 & Fit \\
CFI & 0,90 & & & Fit \\
Parsimonious Fit & $0-1$ & Bigger is Better & 0,701 & \\
PNFI & $0-1$ & Bigger is Better & 0,600 & \\
PGFI & & &
\end{tabular}

Source: Primary data processed, 2021.

The relationship between the influence of the complete model developed in this study needs to be tested for the null hypothesis $(\mathrm{H} 0)$ through the t-test which is common in regression models.

Table 2 - Regression Weight Hypothesis Test Results

\begin{tabular}{llllllll}
\hline & & & Estimate & S.E. & C.R. & P & Label \\
\hline Consumer Trust & $<---$ & Consumer Satisfaction &, 676 &, 107 & 6,884 & ${ }^{* * *}$ & par_13 \\
Repurchase Intention & $<---$ & Consumer Satisfaction &, 231 &, 067 & 3,306 & ${ }^{* * *}$ & par_14 \\
Repurchase Intention & $<---$ & Consumer Trust &, 760 &, 078 & 8,438 & ${ }^{* * *}$ & par_15 \\
\hline
\end{tabular}

Source: Primary data processed, 2021. 


\section{The effect of consumer satisfaction on repurchase intention at Online Store ' $X$ '}

The results showed that consumer satisfaction had a positive and significant effect on repurchase intentions (C.R.=3.306). According to Kotler \& Armstrong (2005), customer satisfaction with a purchase depends on the actual performance of a product, relative to buyer expectations. Customer satisfaction is very important and provides benefits for the company. Customer satisfaction in the short term can be seen from the occurrence of product repurchases and in the long term it will create consumer loyalty to a particular brand due to satisfactory product quality (Fasocah \& Harnoto, 2014). More service provision and customer satisfaction will increase consumers' future use intentions (Chen \& Corkindale, 2008). Intention to repurchase is the tendency of buying behavior from consumers on a product or service that is carried out repeatedly within a certain period of time and actively likes and has a positive attitude towards a product or service, based on experiences that have been carried out in the past (Suryana \& Dasuki, 2013). In contrast to Lestari (2020) it was found that partially customer satisfaction had no significant effect on the intention to reuse online transportation services. Another study by Hellier et al. (2003); Prastiwi (2016) that consumer satisfaction has no significant effect on repurchase intentions. Similar to research conducted by, among others, Kim \& Lough (2007); Fang et al. (2011); Tu et al. (2012); Feng \& Yanru (2013); Huang et al. (2014); Kitapci et al., (2014); Tetanoe \& Dharmayanti (2014); Muslikhah et.al., (2015); Yan et al. (2015); Olii \& Nurcaya (2016); Pastikarani \& Astuti (2016); Dharmayana \& Rahanatha (2017); Putri \& Astuti (2017); Raihana \& Setiawan (2018) show that consumer satisfaction has a positive and significant effect on repurchase intentions.

\section{The effect of consumer satisfaction on consumer confidence in the ' $X$ ' Online Store}

The results showed that consumer satisfaction had a positive and significant effect on consumer confidence (C.R.=6.884). Consumer satisfaction is the evaluation of products and services according to the customer experience as well as the overall measurement of the consuming experience (Joewono and Kubota, 2007). Trust is defined as a belief that the party will find what he wants from the other party, not what the other party fears (Mao, 2010). The relationship between brands and consumers is obtained by building consumer satisfaction with the brand and building consumer trust in the brand (Blackstone, 2000). If consumers believe that the performance of a service is better than they expected, they are sure to be satisfied (Allameh et al., 2015). In contrast to several studies including Dharmayana \& Rahanatha (2017); Muslikhah et.al., (2015) show that consumer satisfaction has a positive and significant effect on repurchase intentions. Other studies by Delgado \& Munuera (2001); Zboja \& Voorhees (2006); Luk \& Yip (2008); Ha et al. (2010) show that if consumer satisfaction increases, brand trust tends to increase. Consumers who are satisfied with a brand can cause consumers to increasingly believe in the brand, in other words, consumers will have a high level of trust if they are satisfied with a brand.

\section{The effect of consumer trust on repurchase intention at Online Store ' $X$ '}

The results showed that consumer trust had a positive and significant effect on repurchase intention (C. $R=8,438$ ). Consumer trust in the company is an invaluable asset for the company (Maima, 2012). According to Sari \& Widowati (2014), brand trust is the willingness of consumers to trust a brand with all the risks because there is an expectation in their minds that the brand will give positive results to consumers so that it will lead to loyalty to a brand. Hellier et al. (2003) stated that repurchase intention is an individual's assessment of repurchasing products from the same company in a situation that has already occurred. The most important component of online purchases is the trust of customers to the online store itself (Giantari et al., 2013). The desires and expectations of consumers to create customer trust which can ultimately lead to purchase intentions (Adji \& Semuel, 2014). Online shopping intention is a desire in consumers to make online transactions (Thamizhvanan \& Xavier, 2013). Mohmed et al. (2013) stated that trust is an important attribute that must be adopted into e-commerce applications. Trust is formed through the honesty of website vendors, personal data security, and payment guarantees (Parastanti et 
al., 2014). According to Nusarika \& Purnami (2015); Suandana et al. (2016), the higher the level of trust, the higher the purchase intention. Supported by several studies including Muslikhah et.al., (2015); Dharmayana \& Rahanatha (2017); Adinata \& Yasa (2018); Yolandari \& Kusumadewi (2018); Saleem, et.al., (2017); Bulut (2015) shows that consumer trust has a positive and significant effect on repurchase intentions. Ha et al. (2010); Turgut \& Gultekin (2015) in their research that brand trust has a positive influence on repurchase intentions. Vigripat \& Chan (2007) in their research that brand trust has a positive direct effect on repurchase intention. Another study by Sam \& Tahir (2009) showed that trust was the most direct influencing factor in predicting online repurchase intentions. In contrast to research conducted by Sari \& Widowati (2014) that brand trust has no significant effect on repurchase intentions.

\section{The role of consumer trust in mediating the effect of consumer satisfaction on repurchase intentions at Online Store ' $X$ '}

The results showed that the role of consumer trust in mediating consumer satisfaction had a positive and significant effect on repurchase intentions (Sobel test $=3.026$ ). Brand trust is the willingness of the average consumer to depend on the ability of a brand to carry out all its uses and functions (Chaudhuri \& Holbrook, 2001). Tjiptono (2012) states that satisfaction is the level of one's feelings after comparing product performance or perceived results with what is expected. According to Regan \& Hing (2009), consumer satisfaction is a level where the needs, desires and expectations of consumers can be met which will result in repeat purchases or continued loyalty. Consumers who are satisfied with a brand or product they consume will repurchase the product (Sumarwan, 2015). Prastiwi (2016) argues that companies must be able to predict their consumers repurchase intentions more accurately because they can serve as a guide for managing company assets and marketing plans. Repurchase intention is purchase intention based on previous purchase experience (Faradiba, 2013). According to Meng et al., (2011), repurchase intention is used to predict whether consumers can become customers in the long term and provide stable profits for the company. According to Kurniasih (2012) the creation of consumer satisfaction can provide considerable benefits, namely the relationship between companies and consumers that is increasingly becoming harmonious as a good basis for consumers to make repeat purchases. Research conducted by Luk \& Yip (2008) that the effect of satisfaction on repurchase intention is not directly but through trust in the brand. Research by Zboja \& Voorhees (2006) explains that brand trust and satisfaction have an impact on repurchase intention which is mediated through retailer trust and satisfaction. Muslikhah et.al., (2015) in their research that brand trust mediates the effect of consumer satisfaction on revisit intentions.

\section{CONCLUSION}

Based on the results of the analysis and discussion that have been carried out previously, the researchers draw the following conclusions, namely consumer satisfaction has a positive and significant effect on repurchase intentions at Online Store ' $X$ '. Consumer satisfaction has a positive and significant effect on consumer confidence in the ' $X$ ' Online Store. Consumer trust has a positive and significant effect on repurchase intentions at the ' $X$ ' Online Store. The role of consumer trust in mediating consumer satisfaction has a positive and significant effect on repurchase intentions at the ' $X$ ' Online Store. Suggestions that can be given to companies are that repurchase interest can be increased for the management of Online Store ' $X$ ' needs to attract the attention of consumers in various ways and provide supporting facilities regarding product information so that consumers always follow information about the latest products offered. Consumer trust can be maintained by always offering security for consumer privacy so that shopping at this online store feels comfortable. Consumer satisfaction can be increased which is expected by management to be able to meet consumer needs by increasing inventory and providing other options according to consumer needs and desires. For further researchers, further researchers are expected to be 
able to dig deeper into factors and other variables that can influence repurchase intentions that were not examined in this study such as price, facilities, promotional strategies, or other independent variables. For researchers who are interested in continuing this research, they can conduct research using different research subjects or samples. Future researchers are expected to be able to pay more attention to characteristics such as age, gender, education, occupation, length of shopping, buying frequency or other characteristics that also have the potential to influence but, in this study, it is not discussed how the influence of respondents' characteristics on research variables

\section{REFERENCES}

1. Adhini dan Khuzaini. 2017. Pengaruh Transaksi Online Shopping dan Kepercayaan Konsumen terhadap Kepuasan Konsumen Pada E-Commerce. Sekolah Tinggi IImu Ekonomi Indonesia (STIESIA) Surabaya. Jurnal IImu dan Riset Manajemen, Volume 6, Nomor 7, Juli 2017. e-ISSN: 2461-0593.

2. Aditya, D. J. 2015. Analisis Pengaruh Kepercayaan, Persepsi Manfaat dan Harga Terhadap Niat Beli Ulang Online Pada Produk Pakaian (Studi Kasus Pengguna Facebook di Kota Pontianak). Jurnal Manajemen Update, 4(3), hal. 1-11.

3. Bloemer, J. dan Schroder, G.O. 2002. Store Satisfaction and Store Loyalty Explained by Customer-and Store Related Factor. Journal of Consumer Satisfaction, Dissatisfaction, and Complaining Behavior, Vol 15. pp. 68-80.

4. Choi, B., and La, S. 2013. The Impact of Corporate Social Responsibility (CSR) and Customer Trust on The Restoration of Loyalty After Service Failure and Recovery. Journal of Services Marketing, Vol. 27, No. 3, pp. 223-233.

5. Dahlstrom, R., Nygard., A., Kimasheva, M., and Ulvnes, A. M. 2014. How Recover Trust in The Banking Industry? A Game Theory Approach to Empirical Analyses of Bank and Corporate Customer Relationship. International Journal of Bank Marketing, Vol. 32, No. 4, pp. 268-278.

6. Dharmayana, A., dan Rahanatha, B. 2017. Pengaruh Brand Equity, Brand Trust, Brand Preference dan Kepuasan Konsumen terhadap Niat Membeli Kembali. E-Journal Manajemen Unud, Vol.6, No.4, 2017.

7. DR. Nischay Kumar Upamannyu, Dr. Shilpa Sankapal. 2014. Effect Of Brand Image On Customer Satisfaction \& Loyality Intention And The Role Of Customer Satisfaction Between Brand Image And Loyality Intention". Vol 3 No 2 Januari 2014.

8. Evans Mambu. 2015. The Influence Of Brand Image, And Service Quality Toward Consumer Purchase Intention Of Blue Bird Manado". Vol 3 No 4 Desember 2015.

9. Gregg, D. G., dan Walczak, S. (2010). The Relationship between Website Quality, Trust and Price Premiums at Online Auctions. Electronic Commerce Research, 10(1), 1-25. https://doi.org/10.1007/s10660-010-9044-2.

10. Hair, J. F., Anderson, R. E., Babin, B. J., dan Black, W. C. 2010. Multivariate Data Analysis: A Global Perspective (Vol. 7). Upper Saddle River, NJ: Pearson.

11. Harris, L. C., dan Goode, M. M. H. 2010. Online service scapes, trust, and purchase intentions. Journal of Services Marketing, 24(3), 230-243. https://doi.org/10.1108/08876041011040631.

12. Haris R., dan Lasika M.D. 2019. Pengaruh Kepercayaan Merek, Kualitas Pelayanan Islami dan Promosi Terhadap Kepuasan Pelanggan Outlet Rabbani di Kota Jambi. ILTIZAM Journal of Shariah Economic Research 3, No. 2 (December 22, 2019): 57, https://doi.org/10.30631/iltizam.v3i2.535.

13. Harrison-Walker, L. Jean. 2001. The Measurement of Word-of-Mouth Communication and an Investigation of Service Quality and Customer Communication as Potential Antecedents. Journal of Service Research, 4(1) Agustus, hal. 60-75

14. Hsu, C., Lin, J. and Chiang, H. 2013. The Effects of Blogger Recommendations on Customers' Online Shopping Intentions. Internet Research, 23(1),pp. 69-88 
15. Kadir, A., Basri, M., dan Rodi. 2018. Pengaruh Kualitas Pelayanan Terhadap Kepuasan, Nilai, Kepercayaan dan Loyalitas Pelanggan Rumah Tangga Pada Perusahaan Daerah Air Minum Kota Kendari. Jurnal Publicuho, 1(1), 28-37.

16. Kim, D. J., Ferrin, D. L., Rao, H. R. 2008. A trust-based consumer decisionmaking model in electronic commerce: The role of trust, perceived risk, and their antecedents. Decision Support Systems, 44(2), 544-564. https://doi.org/10.1016/j.dss.2007.07.001.

17. Kocoglu, D. 2012. Customer Relationship Management and Customer Loyalty; A Survey in a Sector of Bank. International Journal of Business and Social Science Vol. 3 No. 3; February 2012.

18. Kotler, P., dan Keller, K.L. 2016. Manajemen Pemasaran, Edisi 12. Jilid 1 \& 2. Jakarta: PT. Indeks.

19. Lestari, I. 2020. Analisis Tingkat Kepercayaan dan Kepuasan Pelanggan Terhadap Niat Untuk Menggunakan Kembali Layanan Transportasi Online di Era Pandemi Covid-19. Equilibrium Volume 9. No. 1. Tahun 2020 Hal 27 - 35. eISSN 2684-9313. pISSN 20887485.

20. Mariska, Z. H., dan Shihab, M. S. 2016. Pengaruh Dimensi Service Quality Terhadap Kepuasan Tamu Hotel dan Dampaknya Terhadap Behaviour Intention (Studi Kasus pada Hotel Aston Kuningan Suites- Jakarta). JUrnal Manajermen \& Bisnis Sriwijaya, 14(2), 217-23.

21. Mawey, T.C., Tumbel, A.L., dan Ogi, I.W.J. 2020. Pengaruh Kepercayaan dan Kualitas Layanan terhadap Kepuasan Nasabah PT. Bank Sulutgo. Jurnal EMBA . Vol.6 No.3 Juli 2018, Hal. 1198 - 1207. ISSN 2303-1174.

22. McKnight, D. H., dan Chervany, N. L. 2001. Trust theory of relationship marketing. International Journal of Electronic Commerce, 6(2), 35-59.

23. Nataliana, P.D. dan Santosa, E. 2018. Menguji Peran Kepuasan Konsumen Sebagai Variabel Mediasi dalam Hubungan Ekuitas Merek (Brand Equity) dan Kepercayaan (Trust) Terhadap Niat Beli Ulang (Studi pada Oli Yamalube Di Kota Semarang). Equilibrium Jurnal Bisnis dan Akuntansi . Volume XIII, No. 2 (Oktober 2019): 1-18. ISSN: 1978-1180.

24. Norhermaya, Y. A., dan Soesanto, H. 2016. Analisis Pengaruh Kepuasan Pelanggan Terhadap Kepercayaan dan Loyalitas Pelanggan Untuk Meningkatkan Minat Beli Ulang (Studi Kasus Online Store Lazada. co. id). Fakultas Ekonomika dan Bisnis.

25. Palma, M. A., dan Andjarwati, A. L. 2016. Pengaruh Kualitas Produk, Kemudahan, dan Harga Terdapat Niat Beli Ulang dengan Kepuasan Sebagai Variabel Intervening (Studi Pada Pelanggan Produk Fashion Melalui Toko Online di Surabaya). Jurnal Riset Ekonomi dan Manajemen, 16(1), hal. 84-104.

26. Sadeh, S., Sadeh, E., Mousavi, L., Asgari, F. 2011. The Effects of Website Quality Dimensions on Customer Satisfaction in E-Retailing System. Middle-East Journal of Scientific Research, 10(3), 366-369.

27. Safa, N. S., Mandela, N., Africa, S., Safa, N., dan Solms, V. 2016. Customers Repurchase Intention. Formation in,1-9. https://doi.org/10.4102/sajim.v18i1.712.

28. Saleem, Muhammad. Mazhar, dan Naheed. 2017. Impact of Service Quality and Trust on Repurchase Intentions - The Case of Pakistan Airline Industry. Asia Pacific. Journal of Marketing and Logistics. Vol. 29 No. 5, 2017 pp. 1136-1159.

29. Sari, Chacha Andira. 2015. Perilaku Berbelanja Online di Kalangan Mahasiswi Antropologi di Universitas Airlangga. Jurnal AntroUnairdotNet. Vol. 4 No. 2 http://journal.unair.ac.id/filerPDF/auna97cbdaabbfull.pdf.

30. Siagian, H., dan Cahyono, E. 2014. Analisis Website Quality, Trust dan Loyalty Pelanggan Online Shop. Jurnal Manajemen Pemasaran, 8(2), 55-61. https://doi.org/10.9744/pemasaran.8.2.55-61.

31. Sidharta, R. B. F. I., Sari, N. L. A., dan Suwandha, W. 2018. Purchase Intention pada Produk Bank Syariah Ditinjau dari Brand Awareness dan Brand Image dengan Trust sebagai Variabel Mediasi. MIX: Jurnal IImiah Manajemen, 8(3), 562-578. 
32. Solvang, Bernt Krohn. 2007. Satisfaction, Loyalty, and Repurchase: A Study of Norwegian Customers of Furniture and Grocery Stores. Journal of Consumer Satisfaction, Dissatisfaction and Complaining Behaviour,Vol 20. pp. 110-122.

33. Sondoh Jr., Stephen L., Maznah Wan Omar, Nabsiah Abdul Wahid Ishak Ismail, Amran Harun. 2007. The Effect of Brand Image on Overall Satisfaction and Loyalty Intention in the Context of Color Cosmetic. Asian Academy of Management Journal,Vol 12 No 1. pp. 83-107.

34. Statistia. 2017. E-commerce worldwide-Statistics dan facts. Retrieved 10 September 2021 from http://www.statista.com/topics/871/online-shopping.

35. Sugiyono. 2017. Metode Penelitian Kuantitatif, kualitatif dan R \& D). Bandung: Alfabeta.

36. Sugiyono. 2019. Statistika Untuk Penelitian. Bandung: CV Alfabeta.

37. Sumarwan, Ujang. 2015). Perilaku Konsumen: Teori dan Penerapannya dalam Pemasaran. Bogor: Ghalia Indonesia.

38. Suprapti, Ni Wayan Sri. 2010. Perilaku Konsumen. Udayana: University Press.

39. Utomo, P., Endanga, L., dan Yohanes S. 2011. Kepercayaan Terhadap Internet Serta Pengaruhnya Pada Pencarian Informasi dan Keinginan Membeli Secara Online. Jurnal Dinamika Informatika 2(7).

40. Vasic, N; Kilibarda, M, dan Kaurin, T. 2019. The Influence of Online Shopping Determinants on Customer Satisfactions in the Serbian Market. Journal of Theoretical and Applied Electronic Commerce Research. Vol. 14, No. 2, p. 70-89.

41. Wen, C., Prybutok, V. R., \& Xu, C. (2011). An integrated model for customer online repurchase intention. Journal of Computer Information Systems, 52(1), 14-23.

42. Wijayajaya, H. R., dan Astuti, S. T. (2018). The Effect of Trust and Brand Image to Repurchase Intention in Online Shopping. KnE Social Sciences, 3(10), 915-928.

43. Wilson, N., dan Keni. 2018. Pengaruh Website Design Quality dan Kualitas Jasa Terhadap Repurchase Intention: Variabel Trust Sebagai Variabel Mediasi. Jurnal Manajemen dan Pemasaran Jasa. Vol. 11 No. 2 September 2018: 291-310. ISSN: 2442 9732 (Online). Doi: http://dx.doi.org/10.25105/jmpj.v11i2.3006. ISSN: 0216 - 3780 (Print).

44. Wu, Paul C.S., Gary Yeong-Yuh Yeh, ChiehRu Hsiao. 2011. The Effect of Store Image and Service Quality on Brand Image and Purchase Intention for Private Label Brands, Australasian Marketing Journal, Vol 19 Issue 1. pp. 30-39.

45. Yamit, Z. 2013. Manajemen Kualitas Produk dan Jasa. Yogyakarta: Ekonisia.

46. Yang, Chih-Yun. 2009. The Study of Repurchase Intentions in Experiential Marketing- An Empirical Study of The Franchise Restaurant. The International Journal of Organizational Innovation, Vol 2 No 2. pp. 245-261.

47. Yolandari, N.L.D., dan Kusumadewi, N.M.W. 2018. Pengaruh Pengalaman Pelanggan dan Kepercayaan terhadap Niat Beli Ulang Secara online melalui Kepuasan Pelanggan (Studi pada Situs Online Berrybenka.com). E-Jurnal Manajemen Unud. Vol. 7, No. 10, p. 5343-5378. ISSN: 2302-8912. DOI: https://doi.org/10.24843/EJMUNUD.2018.v7.i10.p6.

48. Yu, P.L., Balaji, M.S., and Khong, K.W. 2015. Building Trust in Internet Banking: a Trustworthiness Perspective. Industrial Management \& Data Systems, Vol. 115, No. 2, pp. 235-252.

49. Yuniarti, Y. 2020. Pengaruh Citra Merek Terhadap Niat Beli Ulang dengan Kepuasan Konsumen dan Kepercayaan Konsumen sebagai Mediator. Tesis. Program Pascasarjana Studi Magister Manajemen. Universitas Muhammadiyah Malang.

50. Zhang, Yixiang, Fang, Yulin, Wei, Kee Kwok. Ramsey, Elaine. McCole, Patrick. Chen, Huaping, 2011. Repurchase Intention in B2C E-commerce - A Relationship Quality Perspective. Information \& Management, 48, pp. 192-200.

51. Zendehdel, M., Laily, P. H. B., Bojei, B. B., dan Syuhaily, O. B. 2011. The Effect on Trust on Online Malaysian Students Buying Behavior. Australian Journal of Basic and Applied Sciences 5(12): 1125-1126 